
10

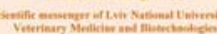
2. 18 11.

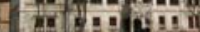
20.9.

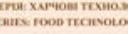
Том 21 Nis 91
Науковий вісник Дьвівського національного університету ветеринарної медицини та біотехнодогій імені С.3. Гжицького. Серія: Харчові технології

\author{
Scientific Messenger of Lviv National University
} of Veterinary Medicine and Biotechnologies.

Series: Food Technologies

ISSN 2519-268X print

https://nvlvet.com.ua/index.php/food

doi: $10.32718 /$ nvlvet-f9114

UDC 664.6:641.8

\title{
Unconventional mushroom components in the recipe of dressing
}

\author{
I. Romashko ${ }^{1}$, S. Maykova ${ }^{2}$ \\ ${ }^{1}$ Stepan Gzhytskyi National University of Veterinary Medicine and Biotechnologies Lviv, Ukraine \\ ${ }^{2}$ Lviv Institute of Economics and Tourism, Lviv, Ukraine
}

Article info

Received 28.01.2019

Received in revised form 27.02.2019

Accepted 28.02.2019

Stepan Gzhytskyi National University of Veterinary Medicine and Biotechnologies Lviv, Pekarska Str., 50, Lviv, 79010, Ukraine. Tel.: +38-093-925-15-65 E-mail:mysh@ukr.net

Lviv Institute of Economics and Tourism, Mentsynskyi Str., 8, Lviv, 79007, Ukraine. Tel.: (032) 255-45-47 E-mail:svitl.majkova@gmail.com
Romashko, I., \& Maykova, S. (2019). Unconventional mushroom components in the recipe of dressing. Scientific Messenger of Lviv National University of Veterinary Medicine and Biotechnologies. Series: Food Technologies, 21(91), 84-88. doi: 10.32718/nvlvet-f9114

The taste of many dishes depends on the sauces that complement them. This includes hot dishes, cold appetizers, and salads. It is proposed to expand the range of restaurant products by using salad dressings with a fungal therapeutic effect. The expediency of introducing functional ingredients into the recipe composition of sauces is considered. The characteristics of mushrooms of maitake and mushroom powder on their basis for the development of medicines and prophylactic appointments were studied. The healing mushroom Maitaique (maitake) became the object of modern science, just recently - only a few decades ago - and to this day the scientists do not cease to see new useful and curative properties. This mushroom comes from the northeast of Japan and China and is quite rare and extremely tasty. Substances that are part of maitake stimulate, activate and prolong the growth of the cells of the body, responsible for the destruction of all alien, including malignant formations. The use of nutrition by healthy people can significantly increase the immunity to diseases, including oncology. Mushroom also affects all types of malignant organisms, slowing down their development and stimulating the breakdown of "bad" cells. One way to enrich the dish with functional ingredients is to use semi-finished products, for example, dry powders based on raw materials that have therapeutic and prophylactic properties. The recipes of mayonnaise dressing sauce using mushrooms maitake are developed. Organoleptic properties of cooked dressing with different contents of mushroom powder are investigated. The physical and chemical characteristics of functional mushroom sauces have been determined and their conformity to the normative requirements has been confirmed. Their compliance with the normative requirements is confirmed. The optimal ratio of components in the composition of mayonnaise dressing with the addition of mushroom powder maitake is established and prospects of further experiments are presented in order to improve it.

Key words: mayonnaise, dressings, sauces, mushrooms, maitake, properties, restaurants, dishes.

\section{Нетрадиційні грибні компоненти в рецептурі дресингу}

\author{
I.C. Ромашко ${ }^{1}$ С.В. Майкова ${ }^{2}$ \\ ${ }^{1}$ Львівський національний університет ветеринарної медицини та біотехнологій імені С.3. Гљсицького, \\ м. Львів, Украӥна \\ ${ }^{2}$ Львівський інститут економіки і туризму, м. Львів, Украӥна
}

Смак багатьох страв залежить від соусів, ще їх доповнюють. Це стосується гарячих страв, холодних закусок, а також салатів. Запропоновано розиирити асортимент ресторанної продукції иляхом використання салатних заправок з фунготерапевтичним ефектом. Розглянуто доцільність внесення функціональних інгредієнтів до рецептурного складу соусів. Вивчено характеристики грибів майтаке і грибного порошку на їх основі для розробки страв лікувально-профілактичного призначення. Цілющий гриб Майтаке (мейтаке) став об'єктом сучасної науки зовсім недавно - лише кілька десятків років тому - $і$ до сьогодні не перестає дивувати вчених новими корисними та лікувальними властивостями. Цей гриб походить з північного сходу Японії та Китаю $і$ є достатньо рідкісним та надзвичайно смачним. Речовини, щзо входять до складу майтаке стимулюють, активізують і подовжують ріст клітин організму, відповідальних за знищення всіх чужорідних, у тому числі, злоякісних утворень. Вжсвання майтаке здоровими людьми дозволяє значного підвищити імунітет організму до захворювань, в тому числі, онкологічних. Гриб такожс 
впливає на всі види злоякісних утворень, сповільнюючи їх розвиток $і$ стимулюючи розпад “поганих” клітин. Одним із способів збагатити страву функціональними інгредієнтами є використання напівфабрикатів, наприклад, сухих порошків на основі сировини, шо володіє лікувально-профілактичними властивостями. Розроблено рецептуру майонезного соусу-дресингу з використанням грибів майтаке. Досліджено органолептичні властивості приготованих дресингів з різним вмістом грибного порошку. Визначено фізико-хімічні характеристики функиіональних грибних соусів та підтверджено їхню відповідність нормативним вимогам. Встановлено оптимальне співвідношення компонентів у складі майонезного дресингу з додаванням грибного порошку майтаке та представлено перспективи подальиих експериментів з метою його вдосконалення.

Ключові слова: майонези, дресинги, соуси, гриби, майтаке, властивості, ресторани, страви.

\section{Вступ}

Харчова індустрія стрімко розвивається, в світі 3'являється безліч нових технологій приготування їжі, нових оригінальних рецептів страв. Довкола нас зазвучали нові слова - красиві, але незрозумілі. Дресинг - одне $з$ таких слів, і це не що інше, як салатна заправка, салатний соус, покликаний поєднати компоненти страви між собою і надати їм певного смаку (пікантного, гострого, пряного, кисло-солодкого і так далі). Термін “дресинг” з'явився близько ста років тому, але тільки зараз почав активно використовуватися кулінарами. Домашній майонез в його безлічі варіацій смаку - це теж салатний дресинг.

Слово дресинг має англійське походження “одяг” для страв, найчастіше салатів. Останніми роками спостерігається масовий інтерес людей до соусів, що містять якомога менше жирів. При цьому цінується те, що дресинги насичені корисними для організму компонентами. Принципова відмінність між майонезом і майонезним соусом полягає у різній калорійності та вмісті яєчного компоненту. Крім того, у майонезів вузька гама смаків, а дресинг можна компонувати під конкретні страви. Новий вигляд соусів на основі майонезу все активніше відвойовує свою частину ринку. Особливо перспективним стає сегмент низько- та середньокалорійних майонезів і майонезних соусів.

Тому метою наших досліджень було запропонувати рецептуру соусу-дресингу на основі майонезу зі зниженим вмістом жирової фази, хорошими органолептичними властивостями, високою стабільністю, а також лікувально-профілактичними характеристиками. Для цього вивчали можливість використання грибного порошку, зокрема порошку гриба майтаке, як компонента майонезного дресингу під час приготування низькокалорійного емульсійного соусу, стійкого до розшарування. Для досягнення поставленої мети необхідно було розв'язати наступні завдання: вивчити лікувальні та профілактичні особливості певних видів грибів; дослідити асортимент кулінарної продукції 3 грибів у національній та зарубіжній кухні; запропонувати рецептуру майонезного соусу з фунготерапевтичним ефектом; дослідити та описати основні характеристики розробленого дресингу 3 використанням нетрадиційного грибного компонента.

\section{Матеріал і методи досліджень}

На основі вивчення профільної літератури при виконанні досліджень застосовували сучасні методи 3 питань технології приготування і розробки асортименту харчової продукції. Крім того, використовували загальнонаукові (комплексний, системний і структурний аналіз), статистичні та економіко-математичні методи, а також проводили порівняльний аналіз різних рецептур приготування страв із залученням грибної сировини. Теоретичною та інформаційною базою дослідження були роботи вітчизняних і зарубіжних фахівців, що вивчають системи громадського харчування, матеріали спеціалізованої періодичної преси: журнали “Експерт”, “Харчова промисловість”, “Практичний маркетинг”, “Харчування і суспільство”, “Ресторанна справа” тощо.

\section{Результати та їх обговорення}

Темп життя суспільства сьогодні невпинно росте. Це безумовно відображається на харчуванні людини, значну частку в якому займає ресторанне господарство. В сучасній світовій кухні трендом стають страви 3 використанням грибів. Це пов'язано з загальним захопленням здоровим харчуванням, а також великим вибором як традиційних для регіону сортів грибів, так і незвичних чи екзотичних. Гриби - поживний харчовий продукт, що є джерелом білків, мінеральних речовин і вітамінів. За хімічним складом гриби близькі до овочів, однак характеризуються вищим вмістом протеїнових сполук (Belinska et al., 2011). Систематична наявність грибів в раціоні людини поліпшує діяльність головного мозку, активізує імунну систему, підвищує загальний тонус організму. Кухарі всього світу стверджують, що немає несмачних грибів - $€$ неправильно приготовані. Оскільки гриби за кількістю корисних речовин і смаковими якостями не поступаються овочам, то можуть посперечатися 3 ними і в асортименті страв на грибній основі.

Інтерес до кухонь різних країн великий, а основою кухонь багатьох народів якраз $є$ страви з грибів. Грибні страви широко використовуються в повсякденному раціоні не лише через особливі смакові якості та високу харчову цінність: вони корисні для здоров'я людини завдяки профілактичному і навіть лікувальному впливу на організм (у світовій медицині існує напрям фунготерапія - лікування грибами) (Borodina, 2018). Водночас грибного смаку страві можна надати, використовуючи різноманітні соуси, що в своєму складі містять грибні компоненти.

До основних складників соусів належать: рідка основа, базові “структуруючі” інгредієнти, смакові компоненти і наповнювачі. Розрізняють дресинги двох видів: ті, що розшаровуються, і емульговані. Емульговані рідкі дресинги складаються з однієї фази, що не розшаровується, для збереження кремоподібної консистенції якої використовують гомогенізацію або змішування $з$ використанням загусників (камеді, кро- 
хмалю, борошна та ін.). Класичні (французькі) дресинги зазвичай містять від 55 до 65\% салатної олії, незважаючи на те, що стандартом передбачено 35\%, оскільки підвищений вміст олії дозволяє досягти кращих органолептичних показників (при низькому вмісті олії камедь або стабілізатори надають продукту в'язкості і слизистості, тимчасом як при вищій жирності соусу 3'являється кремоподібна консистенція, що створює приємні відчуття під час дегустації).

Різноманітні модифікації соусів-дресингів на основі майонезу з'являються при використанні нетрадиційних інгредієнтів або заміні компонентів соусу іншими з метою поліпшення смакових, візуальних, реологічних та інших показників. Завдяки цьому створюється можливість виготовлення нових продуктів 3 лікувально-профілактичними характеристиками, 3 підвищеною біологічною, харчовою i поживною цінністю. Одним 3 напрямків сучасних досліджень в харчовій галузі $€$ розширення асортименту продукції за рахунок внесення в рецептуру виробу компонентів, нетрадиційних для кулінарних традицій певної культури (Zatvora \& Kichan, 2004). Прикладом можуть бути давно відомі, але нехарактерні в українській кухні “східні” гриби майтаке.

Гриб Майтаке - це дивовижний своєрідний гриб, дуже схожий зовні на відомі багатьом гливи, а також звичайний деревний наріст. Він буває досить великих розмірів (до півметра), а його вага може досягати 4 кілограмів. Танцюючий гриб, як його називали ще в 5 столітті китайці і японці, збирали і вживали не тільки в їжу, але й для лікування. Сьогодні цей гриб культивується заради його корисних властивостей, але в деяких районах Китаю і в лісосмугах Японії можна зустріти і дикоростучий майтаке. За давнім повір'ям, перш ніж зірвати гриб, потрібно було виконати особливі ритуальні рухи танцю, адже інакше всі його лікувальні якості втратяться. Саме тому майтаке назвали танцюючим грибом. За іншою версією, бідняки танцювали від радості, знайшовши смачний і поживний гриб.

Корисні властивості майтаке незаперечні, адже ці гриби містять в собі важливі мінерали і вітаміни. Полісахариди, наявні в грибах, справляють імуномоделюючу дію та пригнічують вірус імунодефіциту. Амінокислоти, що також містяться в грибах, стабілізують білковий обмін в організмі людини. Особливістю грибів $є$ їхня здатність послаблювати болі і випадання волосся внаслідок хіміотерапії. Крім того, танцюючий гриб прекрасно регулює вміст цукру в крові - через це його можна рекомендувати тим, хто перебуває в групі ризику з розвитку діабету (Krainiuk et al., 2009). Вживання грибів майтаке знижує загальну втомлюваність, захворюваність різними інфекційними і сезонними вірусними захворюваннями, стабілізує артеріальний тиск крові, особливо рекомендуються для людей 3 порушеннями в роботі щитовидної залози та надниркових залоз. Користь грибів майтаке полягає в пригніченні ними розвитку злоякісних пухлин та підвищенні імунітету до онкологічних захворювань. Ефективність грибів майтаке спостерігається при лікуванні певних видів раку, наприклад сечостатевої системи і молочної залози. Вживання майтаке в післяопераційний період полегшує проходження реабілітації та усуває поширення метастаз. Доброякісні пухлини також піддаються лікуванню цими грибами. Гриб майтаке доцільно ввести в раціон людям 3 цукровим діабетом і зайвою вагою (Deng et al., 2009; Shomori et al., 2009). Хоч цей гриб став об'єктом наукових досліджень відносно недавно (близько тридцяти років тому), однак в мікології його вже встигли назвати “висхідною зіркою”.

Сучасним перспективним напрямком харчової галузі $є$ створення різноманітних майонезних соусів, зокрема розширення їхнього асортименту шляхом залучення нетрадиційних компонентів, особливо тих, що характеризуються вираженими індивідуальними лікувально-профілактичними властивостями. Майонез $є$ емульсією рослинної олії з водною фазою. Ця система для забезпечення однорідності та стійкості в часі потребує додавання емульгаторів, стабілізаторів, структуроутворювачів та загусників. У рецептурі класичного майонезу ці функції забезпечуються внесенням яєць, дія яких синергетично посилюється в кислому середовищі (лимонна або оцтова кислота) в присутності гірчиці (ії білкових компонентів), солі та цукру (що виступають як консерванти і смакові додатки). Майонез $€$ високодисперсною емульсією типу “олія у воді", вміст жиру в якій 77-84\%. Кількість жиру та інтенсивність емульгування впливає на в'язкість і стійкість соусу до розшарування. При зменшенні калорійності продукту лише яєчних компонентів для стабілізації структурно-механічних властивостей емульсійних соусів стає замало, тому багатьма вченими вивчається можливість застосування природних (корисних) речовин, альтернативних традиційним: молочно-білкових концентратів, полісахаридів (пектину, крохмалю тощо), а також різноманітних загусників.

На ринку також представлено багато дресингів, серед них - низькокалорійні майонезні соуси 3 такою типовою рецептурою: рослинна олія (20-30\%), яєчний компонент (3-5\%), вода (60-70\%), крохмаль (3-4\%), оцет $(3-4 \%)$, сіль $(1-1,5 \%)$, цукор (1-2\%), лимонний сік $(0,5-1 \%)$, спеції $(0,5-1,5 \%)$. В рецептурах соусів-дресингів, особливо 3 високим вмістом водної фази (тобто для низькокалорійних продуктів), для загущення та регулювання їх консистенції найчастіше використовують крохмаль. Для приготування ж соусів в умовах ресторанного господарства, де немає необхідності у тривалому зберіганні продукту, з метою формування консистенції можна використовувати компоненти, що характеризуються помітними вологозв'язуючими властивостями, а також мають біологічну і фізіологічну цінність.

Тому нашою пропозицією було вивчити доцільність внесення сухого грибного порошку (на основі гриба майтаке) замість крохмалю у рецептуру низькокалорійного соусу-дресингу (Mjachikova, 2001). Це дозволить зменшити вміст легкозасвоюваного вуглеводу (крохмалю) та підвищити харчову цінність майонезного соусу, наділити продукт лікувальнопрофілактичними властивостями, поліпшити його 
зовнішній вигляд і консистенцію, надати нових смакових та ароматичних відтінків. Для цього досліджували вплив кількості внесеного грибного порошку на органолептичні та фізико-хімічні показники якості майонезного соусу-дресингу. За основу для досліджень використано майонезний соус відомого складу (далі - Контроль). Перелік та вміст компонентів Контролю подано нижче (табл. 1). Для досліджень готували три зразки майонезних дресингів, в яких частку крохмалю у рецептурі Контролю заміняли грибним порошком у кількості 1,0 г (1\% - Зразок 1), 2,0 г (2\% Зразок 2) і 3,0 г (3\% - Зразок 3). Для цього попередньо отримували водно-крохмальну суміш (для Контролю) або водно-крохмально-клітковинну суміш (для дослідних зразків). Суміш повільно нагрівали до $60{ }^{\circ} \mathrm{C}$ при постійному перемішуванні, далі охолоджували до кімнатної температури, не припиняючи перемішувати. Отримана система гусла та забезпечувала необхідну стійкість і в’язкість майбутньому соусу.

\section{Таблиця 1}

Рецептурний склад контрольного майонезного соусу

\begin{tabular}{lc}
\hline \multicolumn{1}{c}{ Компонент рецептури } & Вміст, \% \\
\hline олія соняшникова рафінована дезодорована & 35 \\
цукор білий & 1,5 \\
крохмаль модифікований картопляний & 3,0 \\
сіль кухонна & 1,1 \\
сік лимонний & 1,2 \\
меланж яєчний & 6,0 \\
молоко пастеризоване & 2,0 \\
гірчиця негостра & 2,5 \\
вода питна & 47,7 \\
\hline
\end{tabular}

Органолептичні показники соусу, приготованого за даною рецептурою, такі (табл. 2).

\section{Таблиця 2}

Органолептичні показники контрольного майонезного coycy

\begin{tabular}{|c|c|}
\hline Показник & Характеристика \\
\hline $\begin{array}{l}\text { Зовнішній } \\
\text { вигляд, } \\
\text { консистенція }\end{array}$ & $\begin{array}{l}\text { Однорідна, пухка маса консистенції } \\
\text { густої сметани } 3 \text { поодинокими } \\
\text { пухирцями повітря }\end{array}$ \\
\hline Смак & $\begin{array}{l}\text { Слабкокислий з легкими смаковими } \\
\text { відтінками } \quad \text { порошко-подібних } \\
\text { напівфабрикатів, що входять до } \\
\text { рецептури соусу }\end{array}$ \\
\hline Запах & $\begin{array}{l}\text { Легкий запах порошкоподібних } \\
\text { напівфабрикатів, які входять до } \\
\text { рецептури продукту }\end{array}$ \\
\hline Колір & $\begin{array}{l}\text { Блідо-жовтий, однорідний в усій } \\
\text { масі }\end{array}$ \\
\hline
\end{tabular}

Рецептурний склад дослідних зразків майонезних соусів-дресингів подано у таблиці 3 .

Результати органолептичної оцінки досліджуваних зразків майонезних дресингів з грибним порошком наведено у таблиці 4.

Враховуючи результати органолептичної оцінки, можна вважати найкращим Зразок 3, оскільки його показники найбільш оптимальні щодо поєднання та гармонійності смаку, запаху, зовнішнього вигляду i консистенції. У даному дресингу міститься 3\% мас. грибного порошку.

Для даних зразків дресингів та Контролю визначали деякі фізико-хімічні показники, а саме стійкість емульсії та кислотність у перерахунку на оцтову кислоту. Результати досліджень зведено у таблицю 5.

\section{Таблиця 3}

Рецептурний склад дослідних зразків майонезних соусів-дресингів

\begin{tabular}{lcccc}
\hline \multirow{2}{*}{ Компонент рецептури } & \multicolumn{3}{c}{ Вміст, \% } \\
\cline { 2 - 5 } оронтроль & 3разок 1 & Зразок 2 & 3разок 3 \\
\hline олія соняшникова рафінована дезодорована & 35,0 & 35,0 & 35,0 & 35,0 \\
цукор білий & 1,5 & 1,5 & 1,5 & 1,5 \\
крохмаль модифікований картопляний & 3,0 & 2,0 & 1,0 & - \\
грибний порошок & - & 1,0 & 2,0 & 3,0 \\
сіль кухонна & 1,1 & 1,1 & 1,1 & 1,1 \\
сік лимонний & 1,2 & 1,2 & 1,2 & 1,2 \\
меланж яєчний & 6,0 & 6,0 & 6,0 & 6,0 \\
молоко пастеризоване & 2,0 & 2,0 & 2,0 & 2,0 \\
гірчиця негостра & 2,5 & 2,5 & 2,5 & 2,5 \\
вода питна & 47,7 & 47,7 & 47,7 & 47,7 \\
\hline
\end{tabular}

При заміні крохмалю у рецептурі майонезного дресингу грибним порошком підвищується стійкість дисперсії, але при цьому зростає і кислотність продукту, для стабілізації росту якої можна додатково вно- сити компоненти 3 антиоксидантними властивостями, що може стати предметом подальших досліджень. Загалом за показниками кислотності усі зразки відповідають вимогам стандарту. 
Таблиця 4

Органолептичні показники досліджуваних зразків майонезних дресингів з грибним порошком

\begin{tabular}{|c|c|c|c|}
\hline \multirow{2}{*}{ Показник } & \multicolumn{3}{|c|}{ Характеристика } \\
\hline & Зразок 1 & Зразок 2 & Зразок 3 \\
\hline Колір & $\begin{array}{l}\text { Блідо-бежевий, однорідний в усій } \\
\text { масі }\end{array}$ & $\begin{array}{l}\text { Світло-бежевий, однорідний } \\
\text { усій масі }\end{array}$ & $\begin{array}{l}\text { Бежевий, однорідний в усій } \\
\text { масі }\end{array}$ \\
\hline $\begin{array}{l}\text { Зовнішній вигляд, } \\
\text { консистенція }\end{array}$ & $\begin{array}{l}\text { Однорідна маса консистенції гус- } \\
\text { тої сметани } 3 \text { окремими вкраплен- } \\
\text { нями грибного порошку }\end{array}$ & $\begin{array}{l}\text { Однорідна пухка сметаноподібна } \\
\text { маса } 3 \text { вкрапленнями частинок } \\
\text { грибного порошку }\end{array}$ & $\begin{array}{l}\text { Однорідна густа сметаноподі- } \\
\text { бна маса } 3 \text { вкрапленнями гри- } \\
\text { бного порошку }\end{array}$ \\
\hline Смак & $\begin{array}{l}\text { М'який слабокислий зі смаковими } \\
\text { відтінками порошкоподібного } \\
\text { напівфабрикату, що входить до- } \\
\text { рецептури соусу }\end{array}$ & $\begin{array}{l}\text { Приємний слабокислий з легки- } \\
\text { ми смаковими відтінками порош- } \\
\text { коподібного напівфабрикату, що } \\
\text { входить до рецептури соусу }\end{array}$ & $\begin{array}{l}\text { Слабокислий } 3 \text { смаковими } \\
\text { відтінками порошкоподібного } \\
\text { напівфабрикату, що входить } \\
\text { до рецептури соусу }\end{array}$ \\
\hline Запах & $\begin{array}{l}\text { Легкий приємний грибний аромат } \\
\text { продукту }\end{array}$ & Легкий грибний запах продукту & $\begin{array}{l}\text { Приємний грибний запах про- } \\
\text { дукту }\end{array}$ \\
\hline
\end{tabular}

Таблиця 5

Фізико-хімічні показники дослідних зразків майонезних соусів-дресингів

\begin{tabular}{lcccc}
\hline \multicolumn{1}{c}{ Показник } & \multicolumn{3}{c}{ Характеристика } \\
\cline { 2 - 5 } & Контроль & Зразок 1 & Зразок 2 & Зразок 3 \\
\hline Стійкість емульсії, \% незруйнованої емульсії & 98,0 & 97,5 & 98,5 & 99,0 \\
Кислотність, у перерахунку на оцтову кислоту, \% & 0,42 & 0,45 & 0,47 & 0,58 \\
\hline
\end{tabular}

\section{Висновки}

Створення нового виду емульсійних жирових продуктів - соусів-дресингів, що містять у фізіологічно важливих кількостях необхідні для організму нутрієнти, $є$ актуальним напрямком в комплексі заходів щодо формування збалансованих раціонів. Вони забезпечують корекцію мікронутрієнтного дефіциту з метою поліпшення стану здоров'я споживача і профілактики аліментарно-залежних захворювань. Попит на нові види різноманітних соусів постійно зростає, що $\epsilon$ стимулом для закладів харчування, які їх розробляють. Новинкам пророкують велике майбутнє, хоч значна їх кількість зосереджена у вищому ціновому сегменті.

\section{References}

Belinska, S., Orlova, N., \& Motuzka, Yu. (2011). Kontseptualni zasady harantii bezpechnosti kharchovykh produktiv. Tovary i rynky, 1, 176-182 (in Ukrainian).

Borodina, O. (2018). Celebnye griby [Jelektronnyj resurs]. Rezhim dostupu: https://kedem.ru/glossary/fungi/celebnye-griby (in Russian).

Deng, G., Lin, H., Seidman, A., Fornier, M., D'Andrea, G., Wesa, K., Yeung, S., Cunningham-Rundles, S.,
Vickers, A.J., \& Cassileth, B. (2009). A phase I/II trial of a polysaccharide extract from Grifola frondosa (Maitake mushroom) in breast cancer patients: immunological effects. J Cancer Res Clin Oncol, 135(9), 1215-1221. doi: 10.1007/s00432-009-0562-z.

Krainiuk, L.M., Pasichnyk, K.O., \& Nabokov, I.V. (2009). Rozrobka funktsionalnykh kharchovykh produktiv $\mathrm{z}$ vykorystanniam kultyvovanykh hrybiv. Pytannia tekhnolohii ta hihiieny kharchuvannia: materialy I Vseukr. nauk.-prakt. konf [Donetsk], 8-9 kvit. 2009 r. Donetsk: [Vyd-vo Donets. nats. un-tu ekonomiky i torhivli im. Tuhan-Baranovskoho], 190 (in Ukrainian).

Mjachikova, N.I. (2001). Tehnologija poroshkoobraznogo polufabrikata iz kul'tiviruemyh gribov veshenka obyknovennaja. Visnyk Harkivs'kogo universitetu. Ser.: "Aktual'ni problemy suchasnoi nauky v doslidzhennjah molodyh vchenyh m. Harkova", 506, 194-197 (in Russian).

Shomori, K., Yamamoto, M., Arifuku, I., Teramachi, K., \& Ito, H. (2009). Antitumor effects of a water-soluble extract from Maitake (Grifola frondosa) on human gastric cancer cell lines. Oncol Rep, 22(3), 615-620. https://www.ncbi.nlm.nih.gov/pubmed/19639212.

Zatvora, O., \& Kichan, M.A. (2004). Zdorov'ja i zdorovij sposib zhittja: navch.-vihovnij kurs. Berezne (in Ukrainian). 